\title{
Phenological traits of Maize influenced by integrated management of compost and fertilizer Nitrogen
}

Babar Iqbal ${ }^{1 *}$, Mohammad Tariq Jan ${ }^{1}$, Zar Muhammad ${ }^{2}$, Asad Ali Khan $^{1}$, Shazma Anwar ${ }^{1}$, Imran $^{1}$ and Khurrum Shahzad ${ }^{1}$

1. Department of Agronomy, The University of Agriculture Peshawar, Pakistan

2. Cereal Crops Research Institute, Pirsabak Nowshera, Pakistan

*Corresponding author's email: agronomist19388@yahoo.com

Citation

Babar Iqbal, Mohammad Tariq Jan, Zar Muhammad, Asad Ali Khan, Shazma Anwar, Imran and Khurrum Shahzad. Phenological traits of Maize influenced by integrated management of compost and fertilizer Nitrogen. Pure and Applied Biology. Vol. 5, Issue 1, 2016, pp58-63. http://dx.doi.org/10.19045/bspab.2016.50008

Received: 22/08/2015

Revised: $07 / 12 / 2015$

Accepted: $15 / 12 / 2015$

Online First: $21 / 12 / 2015$

\section{Abstract}

Compost is mixture of organic residues contain animal dung and urine along with other residues, such as fodder ruminant, stubble, weeds and leaves. Composted organic material can be used as a source of important nutrients for sustainable crop productivity. Fertilization of maize with nitrogen is one of the most important management practice which affects growth and yield of the crop. Alternative forms of fertilizers such as manures (farmyard manures, composts, and green manures, liquid manure) can be used as sources of plant nutrients and at the same time increase $\mathrm{N}$ use efficiency and crop yield. Therefore the investigated study was designed to evaluate the response of maize to integrated management of compost type and Fertilizer-N a field trial was carried out at Agronomy Research Farm the University of Agriculture, Peshawar during kharif season 2012. The experiment was laid out in Randomized Complete Block Design (RCBD) having three replications and a plot size of $18 \mathrm{~m}^{2}(4 \mathrm{~m} \times 4.5 \mathrm{~m})$ having 6 rows with $75 \mathrm{~cm}$ apart. All plots except control (no compost) were treated with compost from 3 various sources i.e. cereal, legume and FYM in such a way that $150 \mathrm{~kg} \mathrm{~N} \mathrm{ha}^{-1}$ was ensured based on nitrogen concentration. These plots either were supplemented with half of recommended $\mathrm{N}$.i.e. $75 \mathrm{~kg} \mathrm{ha}^{-1}$ from fertilizer (urea) or without fertilizer-N. Phosphorus was supplied at the rate of $75 \mathrm{~kg} \mathrm{ha}^{-1}$. Data were recorded on days to emergence, days to tasseling, days to silking, days to maturity and plant height. Results revealed that compost type significantly affected all parameters except days to maturity. Minimum days to emergence (6 days) were recorded in control, days to tasseling (56 days) in legume and days to silking (60 days) in FYM based compost with and without Nitrogen respectively. Optimum plant height $(255 \mathrm{~cm})$ was recorded in FYM compost. Mineral nitrogen were non-significant for all parameters. It was concluded from the data, that legume and FYM based composts either supplemented with $\mathrm{N}$ or not, had resulted optimum growth and phenology of maize, and thus is recommended for general cultivation in agroclimatic conditions of Peshawar.

Keywords: Maize (Zea mays L.); Compost types; Nitrogen; Growth and phenology 


\section{Introduction}

Maize is an important kharip crop of Pakistan belongs to family gramineae. It is grown in summer in Pakistan as well as in spring season. It is a multipurpose crop of Pakistan ranked $3^{\text {rd }}$. It is an exhaustive and multipurpose cereal crop that provides food, feed for human and animals whereas raw material for the industries [1]. It has greater nutritional value as it contains about $72 \%$ starch, $10 \%$ proteins, $4.8 \%$ oil, $8.5 \%$ fiber, $3 \%$ sugar and $1.7 \%$ ash [2]. It is the third most important cereal crop after wheat and rice, while in the farming system of Khyber Pakhtunkhawa it ranks second after wheat in importance. It was grown on an area of 1083 thousand ha with total production of 4271 thousand tons and national average yield of $3943 \mathrm{~kg} \mathrm{ha}^{-1}$ in Pakistan [3]. Compost is mixture of organic residues and soil that has been piled, moistened, and allowed to decompose in a pit or heap. It is mixed with soil prior to decay process. It may also contain animal dung and urine along with other residues, such as fodder ruminant, stubble, weeds and leaves [4]. Composted organic material can be used as a source of important nutrients for sustainable crop productivity. Fertilization of maize with nitrogen is one of the most important management practice which affects growth and yield of the crop [5]. $\mathrm{N}$ level has a direct effect on chlorophyll content [6]. Alternative forms of fertilizers such as manures (farmyard manures, composts, and green manures, liquid manure) can be used as sources of plant nutrients and at the same time increase $\mathrm{N}$ use efficiency and crop yield [7]. Crop yield is usually increased by manure application because of the increased nutrients availability and the improved soil structure [8]. Schlegel (1992) [9] found that composted manure plus fertilizer addition resulted in greater grain sorghum (Sorghum bicolor L.) yield than either source applied alone. However, [10] reported that compost increase grain yield of maize over control.

Use of proper organic and inorganic fertilizer combination, is a key factor in crop production for sustainable agriculture. However, there is limited published work about the application of compost manure along with the inorganic $\mathrm{N}$ fertilizer. The objective of this study was to determine the response of maize growth and productivity to compost manure and inorganic $\mathrm{N}$ fertilizer under the agro-climatic condition of Peshawar, Pakistan.

\section{Materials and Methods}

Field experiment was conducted at Agronomy Research Farm of The University of Agriculture Peshawar (Khyber Pakhtunkhawa, Pakistan) during Kharif, season 2012. The experiment was laid out in Randomized Complete Block Design (RCBD) with three replications. Compost quantities were calculated for supplying $150 \mathrm{Kg} \mathrm{N} \mathrm{ha}{ }^{-1}$ based on its chemical composition and applied at sowing either control mineral $\mathrm{N}$ or with half of the recommended fertilizer $\mathrm{N}$ i.e. $75 \mathrm{~kg} \mathrm{~N} \mathrm{ha}^{-1}$. $\mathrm{N}$ content of the composting materials were determined calorimetrically, following kjeldahl procedure [11]. The crop was sown on June 22, 2012. Plot size was $18 \mathrm{~m}^{2}(4 \mathrm{~m} \times$ $4.5 \mathrm{~m}$ ) having 6 rows, $75 \mathrm{~cm}$ apart and $4 \mathrm{~m}$ long. Field was prepared with two ploughing followed by planking. Maize variety, Azam was used as test crop with seed rate of $25 \mathrm{~kg}$ $\mathrm{ha}^{-1}$ and was collected from Agronomy Research Farm, The University of Agriculture Peshawar. All other agronomic practices were carried out uniformly for all plots. Data was recorded by using standard methods according to days to emergence, days to tasseling, days to silking, days to physiological maturity and plant height. Days to emergence was calculated by counting the number of days from planting to date when $50 \%$ plants emerged in each 
plot. Days to tasseling were calculated by counting the number of days from planting to date when about $50 \%$ plants produced tassels in each plot. Days to silking were calculated by counting the number of days from planting to date when about $50 \%$ plants developed silks in each plot. Days to physiological maturity was calculated by counting the number of days from planting to date when about $50 \%$ plant became physiologically mature. Yellowing of husk was taken as sign for physiological maturity. Plant height was calculated by measuring the height from the bottom to the top (Included tassel) of randomly taken 5 plants in each plot and was averaged. Data was statistically analyzed according to the procedure described by Steel et al. (1996) [12] for randomized complete block design and means were separated by least significant differences test $(\mathrm{P} \leq 0.05)$ upon significant $\mathrm{F}$ test.

\section{Results and Discussion}

\section{Days to emergence}

Data concerning days to emergence as affected by compost and nitrogen are presented in table 1. Statistical analysis showed that the effect of compost was significant while that of fertilizer $\mathrm{N}$ was non-significant. The interaction of fertilizer $\mathrm{N}$ and compost was also non-significant for days to emergence. Mean values of the data showed that cereal compost with and without nitrogen delayed days to emergence (8 days) as compared to legume and FYM based compost application (6 days each). Similarly no significant differences for days to emergence were observed among control, legume and FYM based compost. Cereal compost with and without nitrogen delayed days to emergence as compared to legume and FYM compost with and without Nitrogen respectively. This might be due to the compost impact on physical and chemical properties of soil which determines soil aeration, porosity, water retentivity and hence duration to emergence. This is supported by the findings of [13] who reported that compost application affected soil properties.

Table 1. Days to emergence of maize as affected by compost and Nitrogen.

\begin{tabular}{|c|c|c|c|}
\hline \multirow[b]{2}{*}{ Compost } & \multicolumn{2}{|c|}{$\operatorname{Nitrogen}\left(\mathrm{kg} \mathrm{ha}^{-1}\right)$} & \multirow[b]{2}{*}{ Mean } \\
\hline & 0 & $37.5 \$$ & \\
\hline Control & 6 & 6 & $6 \mathrm{~b}$ \\
\hline Cereal based N & 8 & 8 & $8 \mathrm{a}$ \\
\hline Legume Based N & 6 & 6 & $6 \mathrm{~b}$ \\
\hline FYM Based N & 6 & 6 & $6 \mathrm{~b}$ \\
\hline Mean & 6 & 6 & \\
\hline
\end{tabular}

$\$=$ half nitrogen applied at sowing time and half at knee stage

LSD value for compost $(\mathrm{C})$ at $\mathrm{P} \leq 0.05=1.102$

Fertilizer Nitrogen $(\mathrm{N})=\mathrm{ns}$

Interaction $(\mathrm{N} \times \mathrm{C})=\mathrm{ns}$

\section{Days to tasseling}

Data regarding days to tasseling as affected by compost and nitrogen application are presented in table 2. Statistical analysis showed that the effect of organic nitrogen was significant while fertilizer nitrogen was non-significant. The interaction among these were also non-significant for days to tasseling. Mean values of the data revealed that there were delayed tasseling was observed in cereal based compost with and without nitrogen (58 days) as compared to 
legume and FYM based compost (56 days each). Compost incorporation had delayed tasseling, which might be due to more fertilizer availability and improved soil condition and fertility. Delayed tasseling due to higher $\mathrm{N}$ application could be associated with vigorous and prolongs vegetative growth as a result of higher nutrient availability [14]. This finding is supported by [15] who concluded that tasseling in maize was delayed when cereal compost was applied. These results were confirmed and supported by those of [16, 17] they reported that compost application along with different plant population and seed rate influenced phonological characteristics of maize crop. The reason could be that in highest seed rate competition for light, nutrients, water, $\mathrm{CO}_{2}$ and others essential requirements for plants can increase days to tasseling.

Table 2. Days to tasseling, silking, physiological maturity and plant height $(\mathrm{cm})$ of maize as affected by compost and Nitrogen.

\begin{tabular}{lllll}
\hline Compost type & DTT & DTS & DPM & $\begin{array}{c}\text { Plant height } \\
\text { (cm) }\end{array}$ \\
\hline Control & $56 \mathrm{~b}$ & $60 \mathrm{~b}$ & 99 & $182.3 \mathrm{c}$ \\
Cereal & $58 \mathrm{a}$ & $63 \mathrm{a}$ & 98 & $227.5 \mathrm{~b}$ \\
Legume & $56 \mathrm{~b}$ & $60 \mathrm{~b}$ & 98 & $253.3 \mathrm{a}$ \\
FYM & $56 \mathrm{~b}$ & $60 \mathrm{~b}$ & 98 & $255.0 \mathrm{a}$ \\
\hline LSD $(0.05)$ & 1.193 & 1.668 & $\mathrm{Ns}$ & 17.6 \\
\hline 0 & 56 & 61 & 98 & 228.5 \\
75 & 57 & 61 & 98 & 230.6 \\
\hline LSD $(0.05)$ & $\mathrm{Ns}$ & $\mathrm{ns}$ & $\mathrm{Ns}$ & $\mathrm{ns}$ \\
\hline C x N & $\mathrm{Ns}$ & $\mathrm{ns}$ & $\mathrm{Ns}$ & $\mathrm{ns}$ \\
\hline
\end{tabular}

Means followed by different letter (s) within each category are significantly different using LSD test at $\mathrm{P} \leq 0.05$.

\section{Days to silking}

Data about days to silking as affected by compost and nitrogen is shown in (Table 2). Statistical analysis of the data indicated that organic nitrogen had significantly affected days to silking while fertilizer nitrogen had non-significant effect on days to silking. All the interactions were also non-significant for days to silking. Mean comparison of the data indicated that cereal based compost with and without nitrogen had delayed days to silking (63 days) as compared to legume based compost and FYM (60 days each).Similarly no differences were recorded among control, legume based and FYM based compost. Cereal compost had delayed days to silking. Delayed silking due to the increase of $\mathrm{N}$ might be due to the prolonged vegetative period. These results are in line with the findings of [14] who reported that compost application had delayed silking. These results were supported by [16-18] they concluded that compost application may enhance the growth parameters of lately sown maize crop. Rapid plant growth and development with the highest level of compost application probably might be frequent supply of nutrients to the crop plant and might be by the microbial activities with the incorporation of compost to the soil.

\section{Days to physiological maturity}

Data concerning days to physiological maturity as affected by compost and nitrogen is shown in Table 2. Statistical analysis of the data indicated that organic nitrogen and fertilizer nitrogen had nonsignificantly affected days to physiological maturity. Similarly the interactive response 
of fertilizer nitrogen and organic Nitrogen were also found non-significant for days to physiological maturity. Compost incorporation had no effect on days taken to physiological maturity, which might be attributed to the peculiar genetic characteristics of the same variety. This finding is similar to the findings of [19] who reported that compost application had no effect on physiological maturity.

\section{Plant height}

Data regarding plant height at physiological maturity as affected by compost and nitrogen are revealed that compost had significantly affected plant height while fertilizer nitrogen had non-significantly affected plant height. The interaction among both of these were also non-significant for plant height. Mean comparison of the data indicated that FYM based compost with and without nitrogen had increase plant height $(255 \mathrm{~cm})$ as compared to cereal based compost and legume based compost (182.3 $\mathrm{cm})$. These results were supported by [1618] they concluded that compost application may enhance the growth parameters of lately sown maize crop. Rapid plant growth and development with the highest level of compost application probably might be frequent supply of nutrients to the crop plant and might be by the microbial activities with the incorporation of compost to the soil.

Optimum plant height in maize was observed with the application of FYM compost. Compost application had proliferated plant height, which might be due to more nutrients availability in rhizosphere and improved soil condition and fertility. This result is supported by the research work of $[17,20]$ who conducted field experiment and reported that plant height was significantly affected by FYM and fertilizer application. These results were confirmed and supported by those of [16, 18, 21] they reported that compost application along with different plant population and seed rate influenced phonological characteristics of maize crop. The reason could be that in highest seed rate competition for light, nutrients, water, $\mathrm{C} \mathrm{O}_{2}$ and others essential requirements for plants can increase days to tasseling. This is also in line with the report of $[17,22]$ who also reported that plant height was affected when compost was applied to the field.

\section{Conclusion and Recommendation}

It was concluded from the above results that legume and FYM based composts either supplemented with $\mathrm{N}$ or not, produced optimum growth and phenology of maize as compared to those plots treated with $75 \mathrm{~kg} \mathrm{~N}$ $\mathrm{ha}^{-1}$ had similar effects on maize growth and phenology and thus is recommended for general practices of maize cropping system.

\section{Authors' contributions}

Conceived and designed the experiments: B Iqbal, MT Jan \& Z Muhammad, Performed the experiments: B Iqbal, Z Muhammad \& K Shahzad, Analyzed the data: B Iqbal, MT Jan \& Z Muhammad, Contributed reagents/ materials/ analysis tools: AA Khan, S Anwar \& Imran, Wrote the paper: B Iqbal.

\section{References}

1. Khaliq TT, Mahmood \& Masood A (2004). Effectiveness of farm yard manaure, poultry manure and nitrogen for corn productivity. Int J Agric \& Biology 2: 260-263.

2. Chaudhary AR (1993). Maize in Pakistan. Punjab Agri. Res. Cord. Board Univ. Agric. Faisalabad, Pakistan.

3. Pakistan Economic Survey (2011). Agriculture, 2: 17-35.

4. Khalil I \& Jan AA (2002). Manures. Cropping Technology Book. National Book Foundation. P (127), Peshawar, Pakistan.

5. Binder DL, Sander DH \& Walters DT (2000). Maize response to time of $\mathrm{N}$ application as affected by level of nitrogen deficiency. Agron J 92: 12281236. 
6. Eghball B \& Power JF (1999). Composted and non-composted manure application to conventional and no-tillage systems: corn yield and nitrogen uptake. Agron $J$ 91: 819-825.

7. Eghball B (2002). Soil properties as influenced by phosphorus and nitrogenbased manure and compost applications. Agron J 94: 128-135.

8. Matsi T, Lithourgidis AS \& Gagianas AA (2003). Effects of injected liquid cattle manure on growth and yield of winter wheat and soil characteristics. Agron J 95: 592-596.

9. Schlegel AJ (1992). Effect of composted manure on soil chemical properties and nitrogen use by grain sorghum. J Prod Agric 5: 153-157.

10. Ahsok K, Gautam RC, Singh R \& Rana KS (2005). Growth, yield and economics of maize wheat cropping sequences as influenced by integrated nutrient management. Ind J Agric Sci 75(11): 706-711.

11. Bremner JM \& Mulvaney CS (1982). Nitrogen total. In. A.L. Page, Miller and D.R. Keeney, (eds). Method of soil analysis, Part II. 2nd edition. Am. Soc. Agronomy. Madison. WI.

12. Steel RGD, Torrie JH \& Dickey D (1996). Principals and Procedures of Statistics. Mc Graw Hill, USA.

13. Mbah CN \& Nneji RK (2008). Effect of different crop residue management techniques on selected soil properties and grain production of maize. African $J$ of Agri Res 6(17): 4149-4152.

14. Dolan MS, Saleem MF, Cheema MA \& Hammad HM (2006). Effect of poultry manure level on the productivity of spring maize. J Ani \& plant Sci 19(3): 122-125.
15. Li H, Han Y \& Cai Z (2003). Nitrogen mineralization in paddy soil of the Taihu region of China under anerobic condition, dynamics and model fitting. Geoderma 115: 161-175.

16. Imran \& Khan AA (2015). Influence of Compost Application and Seed Rates on Production Potential of Late Sown Maize on High Elevation in Swat Pakistan. J Environ \& E Sci 5(5): 3640.

17. Imran (2015). Effect of germination on proximate composition of two maize cultivars. J Bio agric and $h$ Care 5(3): 123-128.

18. Imran, Khan AA, Ahmad F \& Ullah I (2015). Influence of hydrated calcium sulphate (caso4.2h2o) and nitrogen levels on water infiltration rate and maize varieties productivity in rainfed area of swat, pakistan. $J$ Chem \& M Res 7(3): 15-20.

19. Shah SA, Shah SM, Mohammad W, Shafi M \& Nawaz H (2009). N uptake and yield of wheat as influenced by integrated use of organic and mineral nitrogen. Int J Plant Prod 3: 45-56.

20. Shah STH, Shahid Ibni Zamir M, Waseem M, Ali A, Tahir M \& Waleed BK (2009). Growth and yield response of maize (Zea mays L.) to organic and inorganic sources of nitrogen. Pak j life soc sci 7(2):108-111.

21. Imran \& Khan AA (2015). Grain Yield and Phenology of Maize Cultivars Influenced by Various Phosphorus Sources. J Food Sci \& Q Mang 37: 7478.

22. Ibrahim M, Hassan A, Iqbal M \& Valeem EE (2008). Response of wheat growth and yield to various levels of compost and organic manure. Pak J Bot 40(5): 2135-2141. 